\title{
PENGARUH SEBELUM DAN SESUDAH BERKUMUR DENGAN LARUTAN JERUK NIPIS TERHADAP PERUBAHAN PH SALIVA
}

\author{
Tita Kartika Dewi ${ }^{{ }^{*}}$ Hadiyat Miko $^{2}$
}

${ }^{1,2}$ Dental Therapy, Poltekkes Kemenkes Tasikmalaya, Jawa Barat, Indonesia *titakartikadewi21@gmail.com

\begin{tabular}{ll}
\hline & ABSTRAK \\
\hline Kata kunci: & Tujuan dari penelitian ini adalah mengetahui adanya pengaruh \\
Larutan Jeruk Nipis & sebelum dan sesudah berkumur dengan larutan jeruk nipis. Jenis \\
PH SALIVA & penelitian ini adalah penelitian eksperimen semu (quasi \\
& experiment), dengan pendekatan yang dilakukan adalah dengan \\
& pendekatan pre test dan post test. Populasi dalam penelitian ini \\
& yaitu Mahasiswa Jalur Umum Tingkat 1 Jurusan Kesehatan Gigi \\
& Politeknik Kementerian Kesehatan Tasikmalaya yang terdiri dari \\
& 40 orang sampel diambil dengan cara purposive samling dan yang \\
& memnuhi kriteria sebanyak 30 orang. 30 orang dibagi menjadi 3 \\
& kelompok perlakuan yaitu untuk kelompok I berkumur dengan \\
& konsentrasi 10\%, untuk kelompok II berkumur dengan \\
& konsentrasi 30\%, kelompok III berkumur dengan konsentrasi \\
& $50 \%$. Analisis data dengan menggunakan standar pengujian uji \\
& Paired-Samples T Test. Hasil uji statistik didapat nilai 0,000 maka \\
& dapat disimpulkan ada perbedaan yang signifikan antara pH \\
& sebelum berkumur dan $p H$ sesudah berkumur konsentrasi $10 \% ;$ \\
& $30 \%$ dan $50 \%$.
\end{tabular}

Key word:

Lime Solution

PH SALIVA

\section{ABSTRACT}

The purpose of this study was to determine the effect before and after gargling with lime solution. This type of research is quasiexperimental research, with the approach taken is the pre-test and post-test approach. The population in this study were Level 1 Jurusan Kesehatan Gigi Politeknik Kementerian Kesehatan Tasikmalaya consisting of 40 samples taken by purposive sampling and those who met the criteria of 30 people. 30 people were divided into 3 treatment groups, namely for group I gargling at a concentration of $10 \%$, for group II gargling at a concentration of $30 \%$, group III gargling at a concentration of $50 \%$. Data analysis using the Paired Samples T Test. The statistical test results obtained value of 0,000 , it can be concluded that there is a significant difference between $\mathrm{pH}$ before rinsing and $\mathrm{pH}$ after rinsing, a concentration of $10 \% ; 30 \%$ and $50 \%$. 


\section{PENDAHULUAN}

Kesehatan gigi sebagai salah satu aspek dari kesehatan secara keseluruhan, masalah utama dalam rongga mulut masih sekitar pada karies gigi dan gingivitis (Depkes RI, 2000). Mayoritas orang Indonesia cenderung mengabaikan dalam memelihara kesehatan gigi. Buruknya derajat kesehatan gigi masyarakat di Indonesia dipicu oleh rendahnya kesadaran masyarakat dalam merawat gigi, hal tersebut dipengaruhi oleh perilaku seseorang dalam mengkonsumsi makanan yang manis dan lengket, malas menyikat gigi, serta jarangnya memeriksa diri ke dokter gigi semakin memicu timbulnya penyakit gigi. Data mengenai timbulnya kesehatan gigi di Indonesia sebanyak $80 \%$ terjadi berupa kerusakan gigi, penyebabnya karena makanan yang berkarbohidrat, gigi dan saliva serta kuman yang berinterksi dalam mulut (Zaura, 2007). Bahkan tidak sedikit orang yang memiliki pengetahuan tentang kesehatan gigi tetapi masih terkena ganguan pada penyakit giginya. Hal ini sesuai dengan pendapat pengetahuan yang baik saja tidak cukup untuk mencegah terjadinya peradangan, harus pula dibarengi dengan sikap kesadaran mengenai cara menggosok gigi dan waktu menggosok gigi yang tepat (Miko, dan Nugroho, 2016)

Karies adalah penyakit pada jaringan keras gigi yang disebabkan oleh kerja mikroorganisme. Karies gigi ditandai oleh adanya demineralisasi mineral-mineral email dan dentin, diikuti oleh kerusakan bahan-bahan organiknya (Kidd dan Smith, 2000). Sedangkan menurut Houwink (1993), yang dimaksud dengan karies gigi adalah proses demineralisasi yang disebabkan oleh suatu interaksi antara (produk-produk) mikroorganisme, ludah, bagian-bagian yang berasal dari makanan dam email.

Mengkonsumsi makanan atau minuman tertentu dapat mempengaruhi $\mathrm{pH}$ saliva yang dapat mengganggu kesehatan gigi dan mulut. Saliva adalah cairan kental yang diproduksi oleh kelenjar ludah. Kelenjar-kelenjar ludah tersebut terletak dibawah lidah, daerah otot pipi dan di daerah dekat langit-langit (Ircham, 2006). Menurut Edwina (1992), saliva adalah suatu cairan oral yang terdiri atas campuran sekresi dari kelenjar ludah besar dan kecil yang ada pada mukosa oral. Makanan atau minuman yang mengandung asam sitrat serta memiliki $p H$ rendah seperti sari lemon dan jeruk yang kita konsumsi akan menyebabkan keasaman dalam mulut meningkat, sehingga menyebabkan turunnya $p H$ saliva. Kemudian dapat mengakibatkan proses demineralisasi gigi karena jaringan gigi dapat larut dalam keadaan asam . Dalam hal ini saliva sangat berperan dalam mengatur keasaman $\mathrm{pH}$ rongga mulut, dimana saliva bertindak sebagai buffer (Resmi, 2009). Keasam-basaan $\mathrm{pH}$ adalah derajat asam suatu larutan yang mempunyai ukuran tertentu sesuai dengan derajat keasamannya yang dinyatakan dengan satuan $p H$ (Amerongen, 1991). Jenis makanan seperti karbohidrat dapat diragikan oleh bakteri tertentu yang menghasilkan asam, sehingga meyebabkan perubahan $p H$ (derajat keasaman) dalam waktu 1-3 menit sampai $p H$ dibawah 5 (Kidd and Bechal, 1992).

Derajat asam saliva $(\mathrm{pH})$ dipengaruhi oleh banyak faktor diantaranya adalah kuatnya rangsangan (stimulasi), stimulasi ini dapat berupa rangsangan rasa asam dan manis yang selanjutnya mempengaruhi demineralisasi gigi geligi (Amerongen, 1991). Menurut Bassiouny 2009, erosi gigi merupakan proses berkurangnya mineral yang mengakibatkan jaringan gigi rusak (seperti enamel dan dentin). Proses ini mengakibatkan sebagian struktur gigi menjadi tidak kuat lagi akibat dari asam pada gigi. Terlalu banyak mengkonsumsi minuman asam dalam waktu yang lama menjadi resiko penyebab kerusakan gigi.

Tanaman Citrus aurantifolia (Cristm.) Swingle dikenal di pulau Sumatra dengan nama Kelangsa (Aceh), di pulau Jawa dikenal dengan nama jeruk nipis (Sunda) dan jeruk pecel (Jawa), di pulau Kalimantan dikenal dengan nama lemau nepi, di pulau Sulawesi dengan nama lemo ape, lemo kapasa (Bugis) dan lemo kadasa (Makasar), di Maluku dengan nama puhat em nepi (Buru), ahusi hisni, aupfisis (Seram), inta, lemonepis, ausinepsis, usinepese (Ambon) dan Wanabeudu (Halmahera) sedangkan di Nusa tenggara disebut jeruk alit, 
kapulungan, lemo (Bali), dangaceta (Bima), mudutelong (Flores), mudakenelo (Solor) dan delomakii (Rote), (Chang and Kinghorn, 2001). Jeruk nipis dapat diolah menjadi salah satu minuman asam. Jeruk nipis disamping untuk minuman juga dapat dimanfaatkan sebagai obat. Sehubungan dengan tingginya kadar vitamin $\mathrm{C}$ pada buah jeruk nipis, maka buah jeruk nipis dapat menyembuhkan penyakit gingivitis (gusi berdarah) dan penyakit influenza (Anonim, 2009). Menurut Dalimartha, anggota SP3T (Sentra Pengembangan dan Penerapan Pengobatan Tradisional) DKI Jakarta, air buah jeruk nipis dapat digunakan sebagai penyedap masakan, minuman, penyegar, bahan pembuat asam sitrat, serta membersihkan karat pada logam dan kulit yang kotor. Bisa juga sebagai campuran jamu. Sedangkan menurut Bellovacensis, seorang ahli kimia menyatakan bahwa sari buah jeruk nipis mengandung sejenis asam khusus, yang dewasa ini dikenal dengan nama asam sitrat. Asam sitrat yang terkandung dalam jeruk nipis dapat mengikis lapisan pelindung gigi hingga $84 \%$ sehingga membuat gigi lebih mudah tererosi, sehingga lapisan gigi akan terkikis (Anonim, 2009). Menurut Kamus Besar Bahasa Indonesia edisi ke tiga (2002), efektif adalah ada efeknya (akibatnya, pengaruhnya, kesannya); manjur atau mujarab (tata obat); dapat membawa hasil; berhasil guna (tata usaha, tindakan); mulai berlaku (tata undang-undang, peraturan). Sedangkan definisi dari kata efektif yaitu suatu pencapaian tujuan secara tepat atau memilih tujuan-tujuan yang tepat dari serangkaian alternatif atau pilihan cara dan menentukan pilihan dari beberapa pilihan lainnya. Sugiarti (2008), bahwa konsentrasi larutan jeruk nipis yang perubahan $\mathrm{pH}$ saliva efektif adalah pada konsentrasi $10 \%, 30 \%$, 50\%, yang lebih efektif adalah konsentrasi 50\%. Sedangkan suatu larutan konsentrasi $10 \%$ kurang efektif pada perubahan $\mathrm{pH}$ saliva tetapi dapat menurunkan $\mathrm{pH}$ saliva yang tadinya bersifat basa menjadi netral apabila $\mathrm{pH}$ rongga mulut lebih dari 7

Berbagai macam makanan masuk ke dalam tubuh melalui mulut, makanan yang mengandung karbohidrat atau asam yang kita konsumsi akan menyebabkan keasaman dalam mulut meningkat, sedangkan jaringan gigi dapat larut dalam keadaan asam. Saliva sangat berperan dalam mengatur $\mathrm{pH}$ rongga mulut (Kidd and Bechal, 1992).

Saliva adalah suatu cairan oral yang terdiri atas campuran sekresi dari kelenjar ludah besar dan kecil yang ada pada mukosa oral. Saliva yang terbentuk di rongga mulut, sekitar 90\% dihasilkan oleh kelenjar submaksiler dan kelenjar parotis, 5\% oleh kelenjar sublingual, dan 5\% lagi oleh kelenjar-kelenjar ludah yang kecil. Sebagian besar saliva ini (90\%) dihasilkan pada saat makan, sebagai reaksi atas rangsangan yang berupa pengecapan dan pengunyahan makanan. Pada saat tidak sedang makan, walaupun aliran saliva ini sangat sedikit, saliva merupakan hal yang sangat penting. Pada individu yang sehat, gigi geligi secara terus menerus terendam dalam saliva (resting saliva) sampai sebanyak $0,5 \mathrm{ml}$ yang akan membantu melindungi gigi, lidah, membrane mukosa mulut, orofaring. Pengeluaran saliva akhirnya akan berhenti pada saat tidur sebab pada manusia kelenjar liur tidak berproduksi jika tidak dirangsang (Edwina,1992).

\section{METODE}

Jenis penelitian ini adalah penelitian eksperimen semu (quasi experiment), tujuannya yaitu untuk mengetahui suatu gejala atau pengaruh yang timbul sebagai akibat dari adanya perlakuan tertentu (berkumur larutan jeruk). Adapun pendekatan yang dilakukan adalah dengan pendekatan pre test dan post test (Notoatmodjo, 2002), dapat digambarkan sebagai berikut:

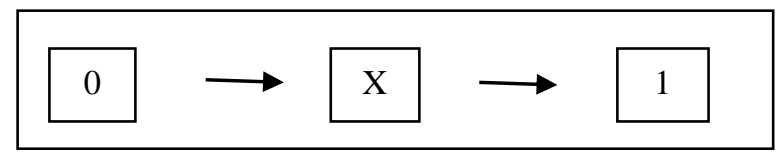


Keterangan:

$0 \quad$ : Pengukuran $p H$ saliva sebelum berkumur

$\mathrm{X}$ : Berkumur dengan larutan jeruk nipis

1 : Pengukuran $p H$ saliva sesudah berkumur

Populasi dalam penelitian ini yaitu Mahasiswa Jalur Umum Tingkat 1 Jurusan Kesehatan Gigi Politeknik Kementerian Kesehatan Tasikmalaya yang terdiri dari 40 orang. Sampel dalam penelitian ini diperoleh dengan cara purposive sampling, yaitu Mahasiswi Jalur Umum Tingkat 1 Jurusan Kesehatan Gigi Politeknik Kementerian Kesehatan Tasikmalaya, sebanyak 30 orang dibagi menjadi 3 kelompok perlakuan yaitu untuk kelompok I berkumur dengan konsentrasi 10\%, untuk kelompok II berkumur dengan konsentrasi 30\%, kelompok III berkumur dengan konsentrasi 50\%. Pengambilan sampel ini yang ciri-cirinya ditentukan oleh peneliti sendiri yaitu a) mahasiswa tingkat I jurusan kesehatan gigi tahun 2010-2011, b) bersedia untuk mengikuti penelitian, c) berjenis kelamin perempuan. Data yang digunakan dalam penelitian ini adalah data primer dan data sekunder. Data primer adalah data yang diperoleh dari objek penelitian yaitu 30 orang Mahasiswi Jalur Umum Tingkat 1 Jurusan Kesehatan Gigi Politeknik Kementerian Kesehatan Tasikmalaya, dengan pengukuran $p H$ saliva, dengan data sekunder berupa telaah buku-buku sumber dan internet yang berkaitan dengan judul penelitian. Pengolahan data dimulai dari Microsoft excel diaplikasikan pada SPSS 14 dan dianalisa dengan menggunakan standar pengujian uji T Dependen atau Paired-Samples T Test.

\section{HASIL DAN PEMBAHASAN}

Penelitian dilaksanakan pada tanggal 31 Mei 2011. Populasi pada penelitian ini adalah mahasiswa tingkat I yang berjumlah 40 orang. Teknik pengambilan sampel dengan menggunakan purposive sampling yaitu yang ciri-cirinya ditentukan oleh peneliti sendiri kepada mahasiswi yang sesuai dengan kriteria inklusi tersebut. Jumlah sampel penelitian ini adalah sebanyak 30 orang yang dibagi menjadi 3 kelompok. Masing-masing kelompok diberi perlakuan yang berbeda yaitu: Kelompok I berkumur dengan larutan jeruk nipis dengan konsentrasi 10\%, kelompok II berkumur dengan larutan jeruk nipis dengan konsentrasi 30\%, kelompok III berkumur dengan larutan jeruk nipis dengan konsentrasi $50 \%$.

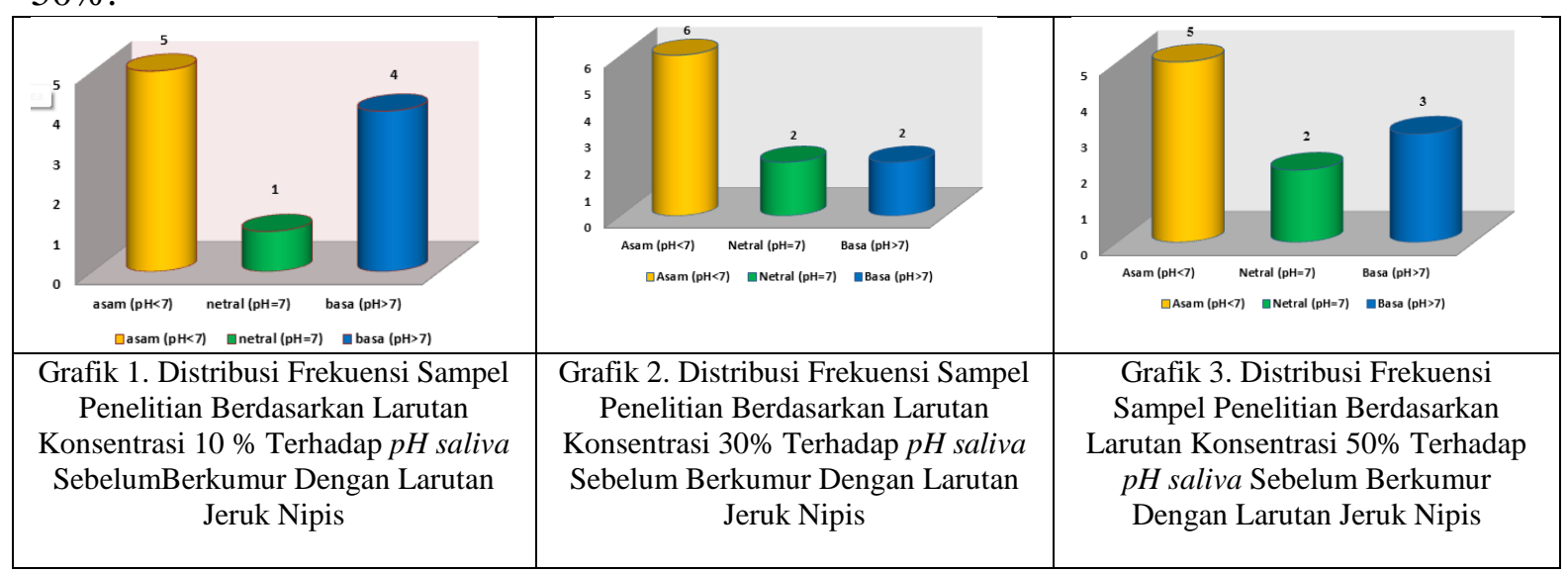

Grafik 1 menggambarkan sebelum perlakuan berdasarkan larutan konsentrasi $10 \%$ sebanyak 10 orang, diperoleh data dengan kriteria $p H$ asam 5 orang $(50 \%)$, kriteria $p H$ netral 1 orang $(10 \%)$, dan kriteria $p H$ basa 4 orang (40\%). Grafik 2 menggambarkan 
sebelum perlakuan berdasarkan larutan konsentrasi $30 \%$ sebanyak 10 orang, diperoleh data dengan kriteria $p H$ asam 6 orang $(60 \%)$, kriteria $p H$ netral 2 orang $(20 \%)$, dan kriteria $p H$ basa 2 orang (20\%). Grafik 3 menggambarkan sebelum perlakuan berdasarkan larutan konsentrasi $50 \%$ sebanyak 10 orang, diperoleh data dengan kriteria $\mathrm{pH}$ asam 5 orang $(50 \%)$, kriteria $p H$ netral 2 orang $(20 \%)$, dan kriteria $p H$ basa 3 orang $(30 \%)$.

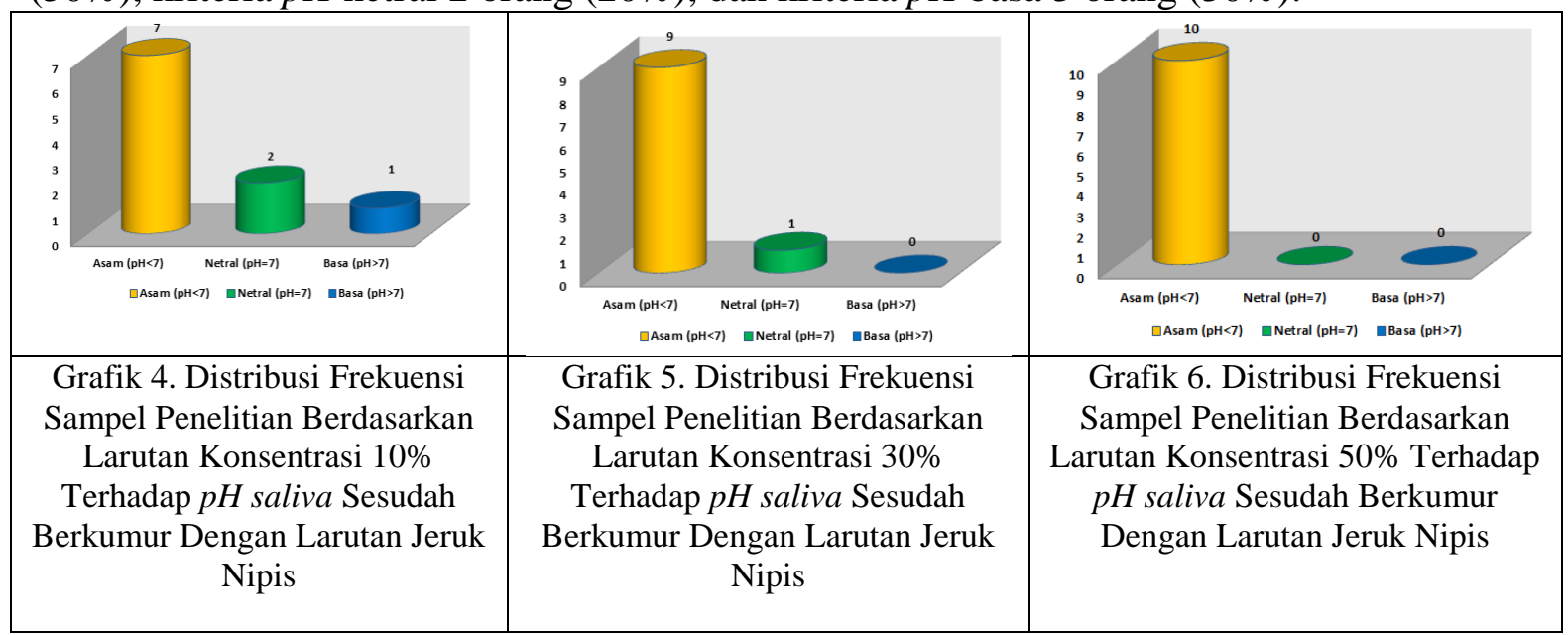

Grafik 4. menggambarkan sesudah perlakuan berdasarkan larutan konsentrasi $10 \%$ sebanyak 10 orang, diperoleh data dengan kriteria $p H$ asam 7 orang (70\%), kriteria $p H$ netral 2 orang $(20 \%)$, dan kriteria $p H$ basa 1 orang (10\%). Grafik 5. menggambarkan sesudah perlakuan berdasarkan larutan konsentrasi 30\% sebanyak 10 orang, diperoleh data dengan kriteria $p H$ asam 9 orang (90\%), kriteria $p H$ netral 1 orang $(10 \%)$, dan kriteria $p H$ basa tidak ada $(0 \%)$. Grafik 6. menggambarkan sesudah perlakuan berdasarkan larutan konsentrasi 50\% sebanyak 10 orang, diperoleh data dengan kriteria $p H$ asam 10 orang (100\%), kriteria $p H$ netral tidak ada $(0 \%)$, dan kriteria $p H$ basa tidak ada $(0 \%)$.

Hasil tesebut memberikan gambaran bahwa hasil penelitian $p H$ saliva sesudah berkumur dengan larutan jeruk nipis adalah asam, namun prosentasi asam lebih besar yaitu pada konsentrasi larutan $50 \%$.

Tabel 1. Hasil Uji Paired Samples T Test Sebelum dan Sesudah Berkumur dengan Larutan Jeruk Nipis pada Konsentrasi $10 \%$

\begin{tabular}{|c|c|c|c|c|c|}
\hline Variabel & Mean & SD & SE & P value & N \\
\hline $\begin{array}{c}p H \text { saliva } \text { sebelum } \\
\text { berkumur } \\
p H \text { saliva } \text { sesudah } \\
\text { berkumur }\end{array}$ & 6,410 & 0,8543 & 0,2702 & 0,000 & 10 \\
\hline
\end{tabular}

Sumber : Data Statistik

Menurut tabel diatas $p H$ saliva sebelum berkumur didapat nilai rata-rata 6,410 dengan standar deviasi 0,8543 . Pada $p H$ saliva sesudah berkumur didapat rata-rata 6,090 dengan standar deviasi 0,8999 . Terlihat nilai mean perbedaan antara $p H$ saliva sebelum berkumur dan $p H$ saliva sesudah berkumur adalah 0,3200 dengan standar deviasi 0,0789. Hasil uji statistik didapat nilai 0,000 maka dapat disimpulkan ada perbedaan yang signifikan antara $p H$ sebelum berkumur dan $p H$ sesudah berkumur konsentrasi $10 \%$. 
Tabel 2. Hasil Uji Paired Samples T Test Sebelum dan Sesudah Berkumur dengan Larutan Jeruk Nipis pada Konsentrasi $30 \%$

\begin{tabular}{|c|c|c|c|c|c|}
\hline Variabel & Mean & SD & SE & P value & N \\
\hline $\begin{array}{c}p H \text { saliva } \text { sebelum } \\
\text { berkumur } \\
p H \text { saliva } \text { sesudah } \\
\text { berkumur }\end{array}$ & 5,960 & 1,1227 & 0,3550 & 0,000 & 10 \\
\hline
\end{tabular}

Sumber : Data Statistik

Menurut tabel diatas $\mathrm{pH}$ saliva sebelum berkumur didapat nilai rata-rata 5,960 dengan standar deviasi 1,1227. Pada $p H$ saliva sesudah berkumur didapat rata-rata 4,900 dengan standar deviasi 1,3848. Terlihat nilai mean perbedaan antara $p H$ saliva sebelum berkumur dan $p H$ saliva sesudah berkumur adalah 1,0600 dengan standar deviasi 0,3806. Hasil uji statistik didapat nilai 0,000 maka dapat disimpulkan ada perbedaan yang signifikan antara $p H$ sebelum berkumur dan $p H$ sesudah berkumur konsentrasi $30 \%$.

Tabel 3. Hasil Uji Paired Samples T Test Sebelum dan Sesudah Berkumur dengan Larutan Jeruk Nipis pada Konsentrasi $50 \%$

\begin{tabular}{|c|c|c|c|c|c|}
\hline Variabel & Mean & SD & SE & P value & N \\
\hline $\begin{array}{c}p H \text { saliva } \text { sebelum } \\
\text { berkumur } \\
p H \text { saliva } \text { sesudah } \\
\text { berkumur }\end{array}$ & 6,120 & 1,3604 & 0,4302 & 0,000 & 10 \\
\hline
\end{tabular}

\section{Sumber : Data Statistik}

Menurut tabel diatas $p H$ saliva sebelum berkumur didapat nilai rata-rata 6,120 dengan standar deviasi 1,3604. Pada $p H$ saliva sesudah berkumur didapat rata-rata 4,300 dengan standar deviasi 1,3047. Terlihat nilai mean perbedaan antara $p H$ saliva sebelum berkumur dan $p H$ saliva sesudah berkumur adalah 1,8200 dengan standar deviasi 0,5731. Hasil uji statistik didapat nilai 0,000 maka dapat disimpulkan ada perbedaan yang signifikan antara $p H$ sebelum berkumur dan $p H$ sesudah berkumur konsentrasi $50 \%$.

Menurut Kamus Besar Bahasa Indonesia edisi ketiga 2002, berkumur adalah berulangulang membasuh mulut dengan menggerak-gerakkan air dan sebagainya di dalam mulut. Cara penggunaan obat kumur yaitu berkumur dengan cara gigi digigitkan, bibir ditutup dan ambil nafas melalui hidung, hingga pipi mengembang-mengempis kurang lebih 30 detik (Vinco, 2008). Jenis makanan seperti karbohidrat dapat diragikan oleh bakteri tertentu yang menghasilkan asam, sehingga meyebabkan perubahan $p H$ (derajat keasaman) dalam waktu 1-3 menit sampai $p H$ dibawah 5 (Kidd and Bechal, 1992). Derajat asam saliva ( $p H$ ) dipengaruhi oleh banyak faktor diantaranya adalah kuatnya rangsangan (stimulasi), stimulasi ini dapat berupa rangsangan rasa asam dan manis yang selanjutnya mempengaruhi demineralisasi gigi geligi (Amerongen, 1991).

Jeruk nipis dapat diolah menjadi salah satu minuman asam. Jeruk nipis disamping untuk minuman juga dapat dimanfaatkan sebagai obat. Sehubungan dengan tingginya kadar vitamin $\mathrm{C}$ pada buah jeruk nipis, maka buah jeruk nipis dapat menyembuhkan penyakit gingivitis (gusi berdarah) dan penyakit influenza (Anonim,2009). 
Menurut Edwina (1992), saliva adalah suatu cairan oral yang terdiri atas campuran sekresi dari kelenjar ludah besar dan kecil yang ada pada mukosa oral. Saliva yang terbentuk di rongga mulut, sekitar 90\% dihasilkan oleh kelenjar submaksiler dan kelenjar parotis, 5\% oleh kelenjar sublingual, dan 5\% lagi oleh kelenjar-kelenjar ludah yang kecil. Sebagian besar saliva ini (90\%) dihasilkan pada saat makan, sebagai reaksi atas rangsangan yang berupa pengecapan dan pengunyahan makanan. Pada saat tidak sedang makan, walaupun aliran saliva ini sangat sedikit, saliva merupakan hal yang sangat penting. Pada individu yang sehat, gigi geligi secara terus menerus terendam dalam saliva (resting saliva) sampai sebanyak $0,5 \mathrm{ml}$ yang akan membantu melindungi gigi, lidah, membrane mukosa mulut, orofaring. Pengeluaran saliva akhirnya akan berhenti pada saat tidur sebab pada manusia kelenjar liur tidak berproduksi jika tidak dirangsang. $p H$ (power of hydrogen) adalah suatu satuan ukuran yang menguraikan derajat tingkat kadar keasaman atau kadar alkali dari suatu larutan. Unit $p H$ diukur pada skala 0 sampai 14. Menurut Sugiarti (2008), bahwa konsentrasi larutan jeruk nipis yang perubahan $\mathrm{pH}$ saliva efektif adalah pada konsentrasi $10 \%, 30 \%$, 50\%, yang lebih efektif adalah konsentrasi $50 \%$. Sedangkan suatu larutan konsentrasi $10 \%$ kurang efektif pada perubahan $\mathrm{pH}$ saliva tetapi dapat menurunkan $\mathrm{pH}$ saliva yang tadinya bersifat basa menjadi netral apabila $\mathrm{pH}$ rongga mulut lebih dari 7.

\section{KESIMPULAN}

Dari hasil penelitian dan pembahasan tentang "Pengaruh Sebelum dan Sesudah Berkumur dengan Larutan Jeruk Nipis Terhadap Perubahan $p H$ Saliva", dapat ditarik kesimpulan sebagai berikut: 1) $p H$ saliva sebelum berkumur dengan konsentrasi $10 \%$ adalah 6,410 dengan standar deviasi 0,8543. Pada $p H$ saliva sesudah berkumur didapat rata-rata $p H$ saliva adalah 6,090 dengan standar deviasi 0,8999 . Terlihat nilai mean perbedaan antara $\mathrm{pH}$ saliva sebelum berkumur dan $\mathrm{pH}$ saliva sesudah berkumur dengan konsentrasi $10 \%$ adalah 0,3200 dengan standar deviasi 0,0789. Hasil uji statistik didapat nilai 0,000 maka dapat disimpulkan ada perbedaan yang signifikan antara $p H$ sebelum berkumur dan $p H$ sesudah berkumur konsentrasi $10 \%$; 2) $p H$ saliva sebelum berkumur dengan konsentrasi 30\% adalah 5,960 dengan standar deviasi 1,1227 . Pada $p H$ saliva sesudah berkumur didapat rata-rata $p H$ saliva adalah 4,900 dengan standar deviasi 1,3848. Terlihat nilai mean perbedaan antara $\mathrm{pH}$ saliva sebelum berkumur dan $\mathrm{pH}$ saliva sesudah berkumur dengan konsentrasi 30\% adalah 1,0600 dengan standar deviasi 0,3806. Hasil uji statistik didapat nilai 0,000 maka dapat disimpulkan ada perbedaan yang signifikan antara $p H$ sebelum berkumur dan $p H$ sesudah berkumur konsentrasi $30 \%$; 3) $p H$ saliva sebelum berkumur dengan konsentrasi 50\% adalah 6,120 dengan standar deviasi 1,3604. Pada $p H$ saliva sesudah berkumur didapat rata-rata $p H$ saliva adalah 4,300 dengan standar deviasi 1,3047. Terlihat nilai mean perbedaan antara $p H$ saliva sebelum berkumur dan $p H$ saliva sesudah berkumur dengan konsentrasi 50\% adalah 1,8200 dengan standar deviasi 0,5731. Hasil uji statistik didapat nilai 0,000 maka dapat disimpulkan ada perbedaan yang signifikan antara $\mathrm{pH}$ sebelum berkumur dan $\mathrm{pH}$ sesudah berkumur konsentrasi $50 \%$.

\section{DAFTAR PUSTAKA}

Amerongen, A. Van Nieuw, 1991, Ludah dan Kelenjar Ludah Arti Bagi Kesehatan Gigi, Gajah Mada University Press, Yogyakarta. 
Anonim, 2009, Jus Jeruk Kikis Email Gigi, http://banjarmasinpost.co.id

Chang, L. C. dan Kinghorn, A. D.,2001, Jeruk Nipis (Citrus Aurantifolia), http://ccrcfarmasiugm.wordpress.com/ensiklopedia/ensiklopedia-tanaman-antikanker/j/jeruk-nipis/

De Leo, F. \& Del Bosco, F.S., 2005, Jeruk Nipis (Citrus Aurantifolia), http://ccrcfarmasiugm.wordpress.com/ensiklopedia/ensiklopedia-tanaman-antikanker/j/jeruk-nipis/

Depkes, 2000, Manajemen Kesehatan Gigi dan Mulut, Depkes R.I, Jakarta.

Edwina, 1992, Dasar - Dasar Karies Penyakit dan Penanggulangannya, Fitramaya, Yogyakarta.

Houwink, B., 1993, Ilmu Kedokteran Gigi Pencegahan, Gajah Mada Universitas Press, Fakultas Kedokteran Gigi UGM, Yogyakarta.

Ircham, 2006, Menjaga Kesehatan Gigi dan Mulut Anak - Anak dan Ibu Hamil, EGC, Jakarta.

Jurusan Kesehatan Gigi, 2005, Preventif Dentistry, Politeknik Kesehatan Kementerian Kesehatan Tasikmalaya, Tasikmalaya.

Kidd, 1992, Dasar-Dasar Karies Penyakit dan Penanggulangannya, Buku Kedokteran: Jakarta.

Kidd, E.A.M., Smith, B.G.N., 2000, Manual Konservasi Restoratif Menurut Pickard, Widya Medika, Jakarta.

Miko, H. dan Nugroho, C., 2016. Gambaran Gingiva Di Sekitar Gigi Molar Ketiga Berdasarkan Status Hormonal Wanita Usia 19-25 Tahun Pada Mahasiswa Keperawatan Gigi Poltekkes Kemenkes Tasikmalaya. Indonesian Oral Health Journal, (1).

Mirantania, 2010, pH meter, http://putrimyra.blogspot.com

Notoatmodjo, S., 2002, Metodologi Penelitian Kesehatan, Rineka Cipta, Jakarta.

Resmi, S., 2009, Kenikmatan yang Menggerus Gigi, http://www.koran-jakarta.com

Sarwo, B., 1993, Jeruk dan Kerabatnya, Penebar Swadaya, Jakarta.

Soendoro, 1998, Peran Saliva Dalam Pencegahan Karies, Kumpul Makalah Pekan Ilmiah Kedokteran Gigi, Ladokgi TNI AL R.E Martadinata, Jakarta.

Sugiarti, F., 2008, Efektivitas Berkumur Dengan Larutan Jeruk Nipis Terhadap Perubahan Warna Gigi 2008, KTI Jurusan Kesehatan Gigi Politeknik Semarang, Semarang.

Tim Penyusun Kamus Pusat Bahasa, 2002, Kamus Besar Bahasa Indonesia, Balai Pustaka, Jakarta

Usman,A., 2010, Pengenceran Larutan, http://lansida.blogspot.com//2010/10/pengenceranlarutan.html

Vinco, 2008, Tanya Jawab Tentang kesehatan Gigi dan Mulut? Di Sini!!, http://www.indicina.net

Zaura, 2007, 77\% Orang Malas Menyikat Gigi, Jurnal Bogor.

2010, Gaya Hidup Sehat,

http://health.kompas.com/read/2010/08/04/09093083/Inilah.26.Khasiat.Jeruk.Nipis.

......, 2010, Kandungan Jeruk Nipis,

http://www.iptek.net.id/ind/pd_tanobat/view.php?id=131 